\title{
Antimicrobial Effects of Camel's Urine in Bacteria Isolated from Clinical Specimens of Wounds Collected from Patients Admitted in Kassala Teaching Hospital, Sudan
}

\author{
S. Jamal Bayed ${ }^{1 *}$, A. Mohammed Issa ${ }^{2}$, Abdul Bagi A. Jubara ${ }^{3}$ and Rabie Ali Babiker ${ }^{3}$ \\ ${ }^{1}$ Department of Medical Microbiology and parasitology, Faculty of Medicine and health \\ Sciences, University of Kassala, Kassala, Sudan \\ ${ }^{2}$ Department of Microbiology and Parasitology, Faculty of Medicine, University of Bahri, \\ Khartoum, Sudan \\ ${ }^{3}$ Faculty of Medicine, University of Gadarif, Gadarif, Sudan \\ *Corresponding author
}

\begin{tabular}{|l|}
\hline K e y w o r d s \\
AST, Camel urine, \\
(MIC), (MBC), \\
$\begin{array}{l}\text { Susceptible and } \\
\text { resistance }\end{array}$ \\
\hline Article Info \\
\hline $\begin{array}{l}\text { Accepted: } \\
\text { 20 November } 2019 \\
\text { Available Online: } \\
\text { 10 December } 2019\end{array}$ \\
\hline
\end{tabular}

\section{A B S T R A C T}

Camel (Camelus dromedarius) urine is one of the traditional antimicrobial agents which are used from the ancient time in different communities for the treatment of so many diseases. It is a scientific miracle of the sunna that the prophet Mohammed "Peace be upon him' mentioned the camel's urine as a medicine in ancient times when there was no electric, microscopic and technology, in the Hadith which mentioned in Sahih Bukhari and also Sahih Muslim. Narrated Anas: Some people from the tribe of 'Ukl (Uraniyyîn) came to the Prophet and embraced Islam. The climate of Medina did not suit them, so the Prophet ordered them to go to the (herd of milch) camels of charity and to drink, its milk and urine (as a medicine). They did so, and after they had recovered from their ailment (became healthy). To assess the efficiency of camel's urine as antimicrobial agent, Minimal inhibitory concentration (MIC) and Minimal bactericidal concentration (MBC) of camels' urine against bacteria causes wound infection. Sixty samples of camel urine were tested for their antimicrobial activity using Mueller Hinton Agar (pour plate method) and tube dilution method in Brain Heart Infusion broth in Bacterial Isolates from Wound Infections of patients admitted in Kassala teaching hospital. Pathogenic Bacteria which include, Staphylococcus aureus, Pseudomonas aeruginosa, Escherichia coli, Proteus mirabilis and Klebsiella pneumonia were used in the research. Undiluted urine of the camel $(100 \%)$ concentrated was found to be bactericidal for all the isolated tested, half concentrated of the urine $(50 \%)$ was bacteriostatic for all the isolated tested. and $25 \%$ concentrated camel urine was found to be resistant for all the isolated tested. No resistant microorganism was found from the isolates of infected wounds for camel urine in high concentration $(100 \%)$. Undiluted and filtered female camel urine of age 5years (100\%) and half diluted (50\%) concentrated were found to be susceptible $100 \%$ for all the isolates of wounds infection. 


\section{Introduction}

Camel urine is one of the traditional antimicrobial agents which are used from the ancient time in different communities for the treatment of so many diseases. It is a scientific miracle of the sunna that the prophet Mohammed "Peace be upon him' mentioned the camel's urine as a medicine in ancient times when there was no electric, microscopic and technology, in the Hadith which mentioned in Sahih Bukhari and also Sahih Muslim.Narrated Anas: Some people from the tribe of 'Ukl (Uraniyyîn) came to the Prophet and embraced Islam. The climate of Medina did not suit them, so the Prophet ordered them to go to the (herd of milch) camels of charity and to drink, its milk and urine (as a medicine). They did so, and after they had recovered from their ailment (became healthy). Camels in the Sudan are mainly found in the northern part in the desert and semi-desert areas of western Sudan, Red Sea State and Eastern Sudan (2). Sudan is considered to be the second largest owner of camels in Africa after Somalia. Estimates of camel population in the country is about 3.6 million head while in Somalia it is about 6.4 million head. Both countries, however, own $70 \%$ of the camel population in Africa Camels in the Sudan is mainly found in the northern part in the desert and semi-desert areas of western Sudan, Red Sea State and Eastern Sudan (2).

\section{Physiology and metabolism of camel's urine}

The kidney can produce very concentrated urine when there is a need for water. The ability to concentrate urine can be determined by the loop of Henle and the structure of the renal medulla. The longer the loop of Henle usually indicates the ability to produce more concentrated urine (2). Water loss can increase quickly in a camel with high temperatures and respiratory frequencies for this reason; the camel has special respiratory mechanisms. Water loss can be reduced by cooling off the exhaled air in the nasal passages which allows for the recovery of water. Hormones play an important role in the conservation of water during times of high heat and dehydration. The concentration of urine that occurs in the kidneys is also partially the result of hormones (3) the urine had a dark, smoky, yellow color and smelt like sweet hay. It had a specific gravity from 1.045 to 1.055 . The volume varied according to the time of observation. During the month of November an average of about 4 liters were obtained. During the colder weather this volume increased to more than 6 liters. As already reported when the animal was deprived of water for 10 days the volume of urine secreted fell to $1,800 \mathrm{ml}$.

\section{Composition of camel urine}

Laboratory tests indicate that camel's urine contains high levels of potassium, albuminous proteins, and small amounts of uric acid, sodium and creatine (4) The analysis of camel's urine appeared the presence of calcium, magnesium, sodium, inorganic phosphorous, urea, uric acid and creatinine. (5) Camel's urine contains a number of healing factors such as antibiotics (bacteria that are present in it, salts and urea). The camel possesses an immune system that is highly equipped to combat funguses, bacteria and viruses, because it contains antibodies (6).

Camel's urine had a pale yellow color when it is fresh and turn to dark yellow gradually, the odor is differ according to the different of the plants and it is different than the odor of human urine, and the taste is highly salty (6). Researchers in Belgium have developed a new generation of drugs consisting of extremely small antibodies - called nanobodies - that can target tumour cells (http://www.drug researcher.com) (Fig. 1, 2, 3, 4 and 5). 


\section{Effect of Camel's urine on diseases}

Skin diseases: Camel's urine is efficacious in the treatment of skin diseases such as ringworm, tinea and abscesses, sores that may appear on the body and hair, and dry and wet ulcers (Al-Jazeerah al-Sa'oodiyyah newspaper 2000).

Liver cirrhosis: Ahmadani in 2001 experimented with camel's urine and gave patients of liver cancer, liver cirrhosis and ascites calculated doses of camel urine for 15 days.

\section{Dropsy}

Ahmadani also explained that dropsy results from a deficiency of albumin or potassium, and the urine of camels is rich in both of these. He suggested that the best types of camels for using the urine as a remedy are young camels. The experiment began by giving each patient a daily dose of camel's urine mixed with camel's milk to make it palatable. Fifteen days after the beginning of the experiment, the patients' stomachs grew smaller and went back to their normal size. He said that he examined the patients' livers with ultrasound before the study began, and he found out that the livers of fifteen out of the twenty-five were in a cirrhotic state, and some of them had developed cirrhosis of the liver as the result of bilharzias. All of the patients responded to treatment with camel's urine, and some of them continued, by their own choice, to drink a dose of camel's urine every day for a further two months (7).

\section{Blood sugar}

It caused a noticeable reduction in patients' sugar levels. In another experiment, Ahmadani administered doses of camel's urine to diabetes patients. The blood sugar decreased remarkably after one year of drinking camel's urine (7).

\section{Digestive system}

Camel's urine may also be used to treat the digestive system and to treat some cases of cancer who stated that the research that she had undertaken on camel urine proved that it was effective in destroying micro-organisms such as fungus, yeas and bacteria. Camel's urine may also provide a remedy for abdominal complaints, especially those of the stomach and intestine (8).

\section{Leukemia}

"Alkabarity" mentioned that the camel's urine had affective reaction in some cases of leukemia who mentioned that some of Bedouin people they used camel's urine mixed with its milk as morning drink for the treatment of leukemia. In the above mentioned diseases the camel's urine is used internally as morning drink for different periods of time according to the disease (9).

\section{Insect bites}

Camel urine can also provide protection against insect bites.

\section{Blood cholesterol}

Ayed Al-Harthi an employee at a hospital said, "I suffer from high-blood cholesterol because of bad eating habits like eating Kabsah every night. I tried many medications, but unfortunately they are only good for short periods of time." "Somebody advised me to try to drink camel urine every night". Then I did a blood test, the result was nice, my cholesterol dropped to the normal level.

\section{Hair loss, baldness and dandruff}

It also helps the hair to grow and become strong and thick, and it helps to prevent hair loss and baldness, and can be used to treat dandruff. Camel's urine may also be used to 
combat disease by using bacteria extracted from it. It was used to treat a girl who was suffering from an infection behind the ear that was accompanied by pus weeping from it and painful cracks and sores. It was also used to treat a girl who was unable to extend the fingers of her hands because of the presence of so many cracks and sores, and whose face was almost black with pimples (8).

\section{Blood clots}

One of the medicines used to treat blood clots is a compound called fibrinoltics which works by changing a substance in the body from its inactive form, plasminogen, to its active form, plasmin, in order to dissolve the substance that causes clotting, Fibrin. One of the components of this compound is called urokinase, which is produced by the kidneys or from the urine, as indicated by the name "uro" (4) It is a remedy for low libido, and it aids in bone growth in children and in Strengthening the heart muscles.

\section{Cancer drugs from camel antibodies}

Researchers in Belgium have developed a new generation of drugs consisting of extremely small antibodies called nanobodies that can target tumour cells (http://www.drug researcher.com). Dr. Faten Abdel-Rahman Khorshid is responsible for one of the Kingdom's greatest national achievements in the field of science for her work which began with the urine of camels and concluded in a potential cure for cancer. After spending more than five years in lab research, this Saudi scientist and faculty member from King Abdul Aziz University (KAAU) and President of the Tissues Culture Unit at King Fahd Center for Medical Research, has discovered that nanoparticles in the urine of camels can attack cancer cells with success. Her work began with experiments involving camel urine, cancer cells found in patients' lungs and culminated in injecting mice with leukemic cancel cells and camel urine to test the results. Speaking to the Saudi Gazette, Dr. Khorshid claimed that she was inspired by Prophet Muhammad's (pbuh) medical advice and that camel urine consists of natural substances that work to eradicate malignant cells and maintain the number of healthy cells in cancer patient (10) Camels mostly feed in all types of plants and some of these plants (desert plants) contain antibiotics which secreted in the camel's urine (11). Camel milk also can be used in the treatment of pulmonary Tuberculosis and anaemia. (10) Patients who suffered from tuberculosis for the past 7-8 years and who did not receive regular treatment were divided into two groups, T1 and T0 of 8 and 6 patients, respectively. T1 patients were given a diet supplemented with raw camel milk at $1 \mathrm{~kg} /$ day, while T0 patients were given dairy milk through 10 weeks. Both groups received an almost similar treatment with regular meals from the TB hospital.

The clinical symptoms, bacteriological, radiological, haemato-biochemical, immunoglobulins, Mantoux test and body weight were recorded before and at the completion of the experiment. At the end of the experiment there was no cough, expectoration, breathlessness and chest pain in the T1 group. Furthermore, the acid fast bacillus (AFB) status was found to be negative in $\mathrm{T} 1$ group, whereas it remained positive in the T0 group.. These results suggest that there was a positive benefit of camel milk supplementation in TB patients (10).

\section{Infection of burns}

The large moist exposed surface of burns becomes colonized by bacteria within 24 hours. Staph.aureus. is the commonest isolate from burns, followed by Ps. aerogenosa. (12) It's proved that camel urine has a fungicidal effect (Aspergillus niger) and also effect on Candida albicans. (8) 


\section{Materials and Methods}

Methods: sixty samples of camel's urine were tested for their antimicrobial activity using Mueller Hinton Agar.; all isolates from wound infection patients tested were human sources of Kassal teaching hospital S. aureus, E. coli; Proteus mirabilis, Klebsiella pneumoniae, were used in the research.

\section{Study design}

This study was conducted at Kassala teaching hospital, Kassala town, Sudan. This study designed to select urine, from healthy female virgin camels of age 5 years which feeds on natural plants near Kassala town with application on pathogenic bacteria isolated from patients suffering from wounds infection, attended in outpatient and inpatient departments of Kassala teaching hospital. There are different tribes in the state bread camels like BeniAmir, Hadundowa, Rashaida, Shukriya and others

\section{Period of the study}

The survey was conducted during the period October 2014up to June 2016.

\section{Camel urine collection}

The camel's urine was collected from female camel Camelus dromedaries of age 5 years (5 ) .

\section{Methods of camel urine collection}

1. Tashweel technique: Described by (4) M.Sc. thesis - aljazera university, Sudan. 2. Normal urination: usually at early morning. 3. By twisting the tail of the camel (new method) 4. By blocking the camel while walking or running (new method).No references or literature is available for the two new methods so I suggest to nominate as Twisting-J method and Blocking $-\mathrm{J}$ method.
All camel urine samples were collected by the above mentioned methods, from a healthy female virgin camel of age 5 years, on sterile clean containers and stored in ice bag container and then stored in the refrigerator at temperature of $4^{\circ} \mathrm{c}$.are seems to be identical according to the alkaline $\mathrm{PH}$ (8.15-9.01).

Camel urine samples tested for the growth of microorganisms, $\mathrm{PH}$, and antimicrobial susceptibility test (pour plate method and tube diluting methods). All camel urine samples were identical according to alkaline $\mathrm{pH}$ of the camel urine. Camel urine samples can be untreated (normal) fresh urine or neutralized urine by HCL (10\%) and high concentrated urine by boiling method till $20-30 \%$ of the total volume.

\section{pH of camel urine}

\section{McFarland standards}

A $0.5 \mathrm{McFarland}$ standard is prepared by mixing $0.05 \mathrm{~mL}$ of $1.175 \%$ barium chloride dihydrate $\left(\mathrm{BaCl}_{2} \cdot 2 \mathrm{H}_{2} \mathrm{O}\right)$, with $9.95 \mathrm{~mL}$ of $1 \%$ sulfuric acid $\left(\mathrm{H}_{2} \mathrm{SO}_{4}\right)$. The standard can be compared visually to a suspension of bacteria in sterile saline or nutrient broth. If the bacterial suspension is too turbid, it can be diluted with more saline. If the suspension is not turbid enough, more bacteria can be added. A McFarland 0.5 standard was prepared and quality controlled prior to beginning susceptibility testing. McFarland 0.5 standard tube was tightly sealed to prevent evaporation and stored in the dark; the standard can be stored for up to 6 months.

The McFarland standard was used to adjust the turbidity of the inoculum for the susceptibility test. The $0.5 \mathrm{McFarland}$ was prepared by adding $0.5 \mathrm{ml}$ of a 1.175 $\%(\mathrm{wt} / \mathrm{vol})$ barium chloride dihydrate $\left(\mathrm{BaCl}_{2} \cdot 2 \mathrm{H}_{2} \mathrm{O}\right.$ ) solution to $99.5 \mathrm{ml}$ of $1 \%$ ( $\mathrm{vol} /$ vol) sulfuric acid. Seal the McFarland standard tubes with wax, Para film, or some 
other means to prevent evaporation. Bacterial suspension of $0.5 \mathrm{McF}$ arland standards, which prepared from the selected colonies which immersed onto a tube of distilled water $(5 \mathrm{ml})$, then compared with.05 McFarland standards.

\section{API 20 E system}

The API 20E is fast identification system combines some conventional tests and allows the identification of a limited number of Gram-negative Enterobacteriaceae or nonEnterobacteriaceae. The test systems are stored in 20 small reaction tubes, which include the substrates. A identification is only possible with microbiological culture. To guarantee a comparability of different samples, we have followed the instructions of the manufacturer.

Before starting a test, we made sure that, the culture was an Enterobacteriaceae or not. This system is developed for quick identification of clinical relevant bacteria, because of it, only known bacteria can be identified (10).

\section{Pour plate method}

Mueller Hinton agar medium which prepared by the addition of different camel urine concentrations instead of distilled water (13). The whole surface of Mueller Hinton agar which prepared by different concentrations of camel urine were swabbed with 0.5 McFarland of E. coli and S. aureus separately.

Plates $(100 \%, 50 \%, 25 \%$ and $12.5 \%)$ were Incubate at $37^{\circ} \mathrm{C}$.for $18-24$ hours. The resistant organisms for different antibiotics are tested for the effect of camel urine in the form of growth (resistant) and no growth as susceptible.

\section{Tube dilution method}

Tube 1 contains $4 \mathrm{ml}$ of only concentrated filtered camel urine that is $100 \%$, Transfer 2 $\mathrm{ml}$ of Brain heart infusion broth into the empty test tubes starting with -ve control. Then transfer $2 \mathrm{ml}$ from tube 1 , to tube 2 , shake well $\&$ from 2 to 3 , shake well\& repeat this for $4 \&$ 5 , then reject $2 \mathrm{ml}$ from test tube 5 .

$0.2 \mathrm{ml}$ culture of $0.5 \mathrm{McFarland}$ of bacterial suspension form $S$. aureus and $E$. coli was added to tubes $1,2,3,4,5$ and +ve control. Incubate at $37 \mathrm{C}$ for $24 \mathrm{hrs}$ (14). MIC: the lowest concentration of the antibiotic required to inhibit the growth of microorganism. Negative control: media only (Brain heart infusion broth) to test the sterility of the medium. Positive control: media + culture to test the growing ability of the medium. Note: MIC determination is always done by 2 fold serial dilution of the antimicrobial agent. The minimal bactericidal concentration (MBC) can be determined by subculturing the contents of the tubes of MIC showing no growth onto antibiotic-free liquid medium and examining for bacterial growth.

\section{The results of camel urine}

Camel urine samples tested for the growth of microorganisms, $\mathrm{PH}$, and antimicrobial susceptibility test (Disk diffusion and tube diluting methods). The result $s$ of the healthy camel urine samples for the above mentioned tests were as following:

\section{Results of pH of camel urine}

From the table of camel urine $\mathrm{pH}$ the results were $99 \%$ alkaline reaction and so that all camel urine specimen seems to be identical (Fig. 6).

\section{Results of the growth of microorganisms on camel urine}

No bacterial growth was seen when sample of urine cultured onto blood agar and MacConky the results of camel urine samples (Fresh and filtered) which were inoculate onto Blood agar 
and MacConky agar were negative for the growth of microorganisms. All camel urine samples were collected by the above mentioned methods, from a female virgin camel of age 5 years, on sterile clean containers and stored in ice bag container and then stored in the refrigerator at temperature of 4 oc.are seems to be identical according to the alkaline $\mathrm{pH}(8.15-9.01)$.

The results of antimicrobial susceptibility tests of camel urine

The results of antimicrobial susceptibility tests of camel urine proved that all camel urine samples of the different concentrations had an effect on the bacteria of wounds infection.
The results of resistant organisms for different antibiotics are susceptible for the effect of camel urine as shown in table 1 and Figure 7.

\section{Different concentrations of camel urine on Blood agar}

100\%: No growth (Staphylococcus aureus \& E.coli)

50\%: No growth (Staphylococcus aureus \& E. coli)

$25 \%$ Growth (Staphylococcus aureus \& E. coli)

$12.5 \%$ Growth (Staphylococcus aureus \& E. coli)

Table.1 Effect of camel urine of different concentration on (Antibiotic resistant) pathogenic bacteria isolated from wounds infection in Moeller Hinton agar and Tube diluting method (B.H.I. broth)

\begin{tabular}{|c|c|c|c|c|c|}
\hline \multirow[t]{2}{*}{ Isolates } & \multicolumn{3}{|c|}{ Camel urine concentrations } & \multirow[t]{2}{*}{ IC } & \multirow[t]{2}{*}{ BC } \\
\hline & $100 \%$ & $50 \%$ & $25 \%$ & & \\
\hline $\begin{array}{c}\text { Staphylococcus } \\
\text { aureus }\end{array}$ & $\begin{array}{l}\text { No growth } \\
\& \text { No turbidity }\end{array}$ & $\begin{array}{l}\text { No growth } \\
\& \text { No } \\
\text { turbidity }\end{array}$ & $\begin{array}{l}\text { Growth\& } \\
\text { turbidity }\end{array}$ & $50 \%$ & $100 \%$ \\
\hline Escherichia coli & $\begin{array}{l}\text { No growth } \\
\& \text { No turbidity }\end{array}$ & $\begin{array}{l}\text { No growth } \\
\& \text { No } \\
\text { turbidity }\end{array}$ & $\begin{array}{l}\text { Growth\& } \\
\text { turbidity }\end{array}$ & $50 \%$ & $100 \%$ \\
\hline $\begin{array}{c}\text { Pseudomonas } \\
\text { aeruginosa }\end{array}$ & $\begin{array}{l}\text { No growth } \\
\& \text { No turbidity }\end{array}$ & $\begin{array}{l}\text { No growth } \\
\& \text { No } \\
\text { turbidity }\end{array}$ & $\begin{array}{l}\text { Growth\& } \\
\text { turbidity }\end{array}$ & $50 \%$ & $100 \%$ \\
\hline $\begin{array}{l}\text { Klebsiella } \\
\text { aerogense }\end{array}$ & $\begin{array}{l}\text { No growth } \\
\& \text { No turbidity }\end{array}$ & $\begin{array}{l}\text { No growth } \\
\& \text { No } \\
\text { turbidity }\end{array}$ & $\begin{array}{l}\text { Growth\& } \\
\text { turbidity }\end{array}$ & $50 \%$ & $100 \%$ \\
\hline Proteus mirabilis & $\begin{array}{c}\text { No growth } \\
\text { \&No } \\
\text { turbidity }\end{array}$ & $\begin{array}{c}\text { No } \\
\text { growth } \\
\text { \&No } \\
\text { turbidity }\end{array}$ & $\begin{array}{l}\text { Growth\& } \\
\text { turbidity }\end{array}$ & $50 \%$ & $100 \%$ \\
\hline
\end{tabular}

IC: inhibitory concentration

BC: bactericidal concentration 
Fig.1 Shows camel urine collection by a new method suggested to be named as Twisting Jmethod. Nomads from Bani Aamer tribe in Kassala

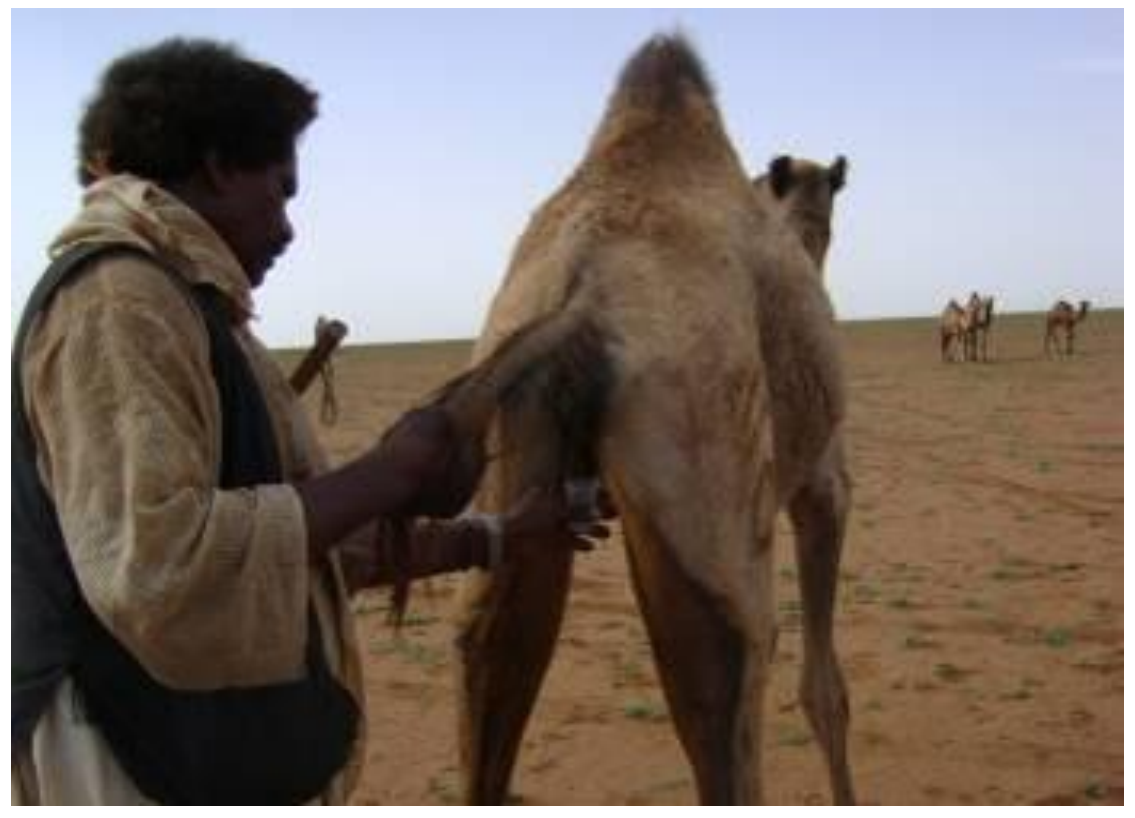

Fig.2 Shows camel urine collection by a new method suggested to be named as Twisting Jmethod. Nomads from Rashaida tribe in Kassala

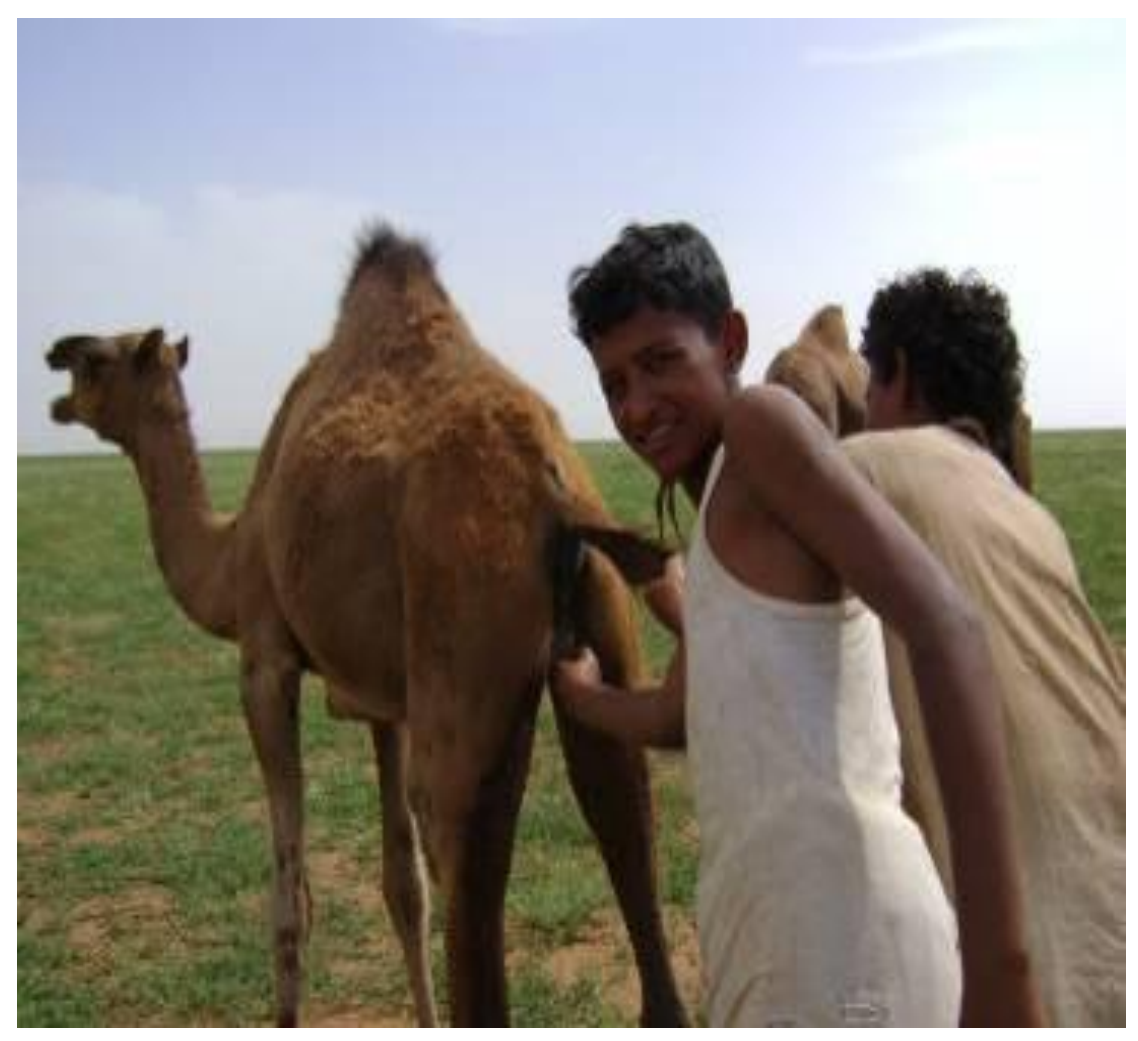


Fig.3 Camel urine collection by Rashaida method

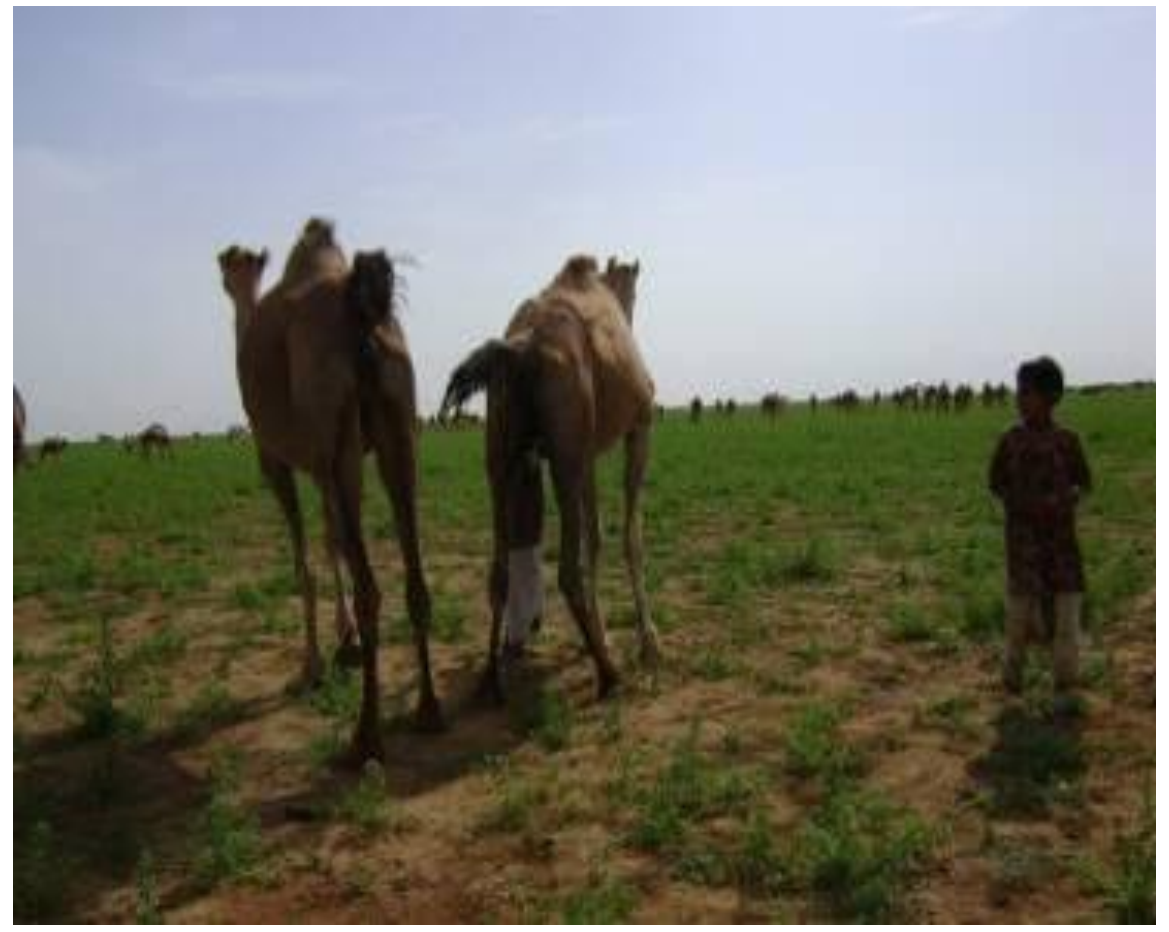

Fig.4 Shows Camel urine collection by Tashweel method describe by Mohammed O'haj 1998. in Bani Aamer camel herders area (Kassala)

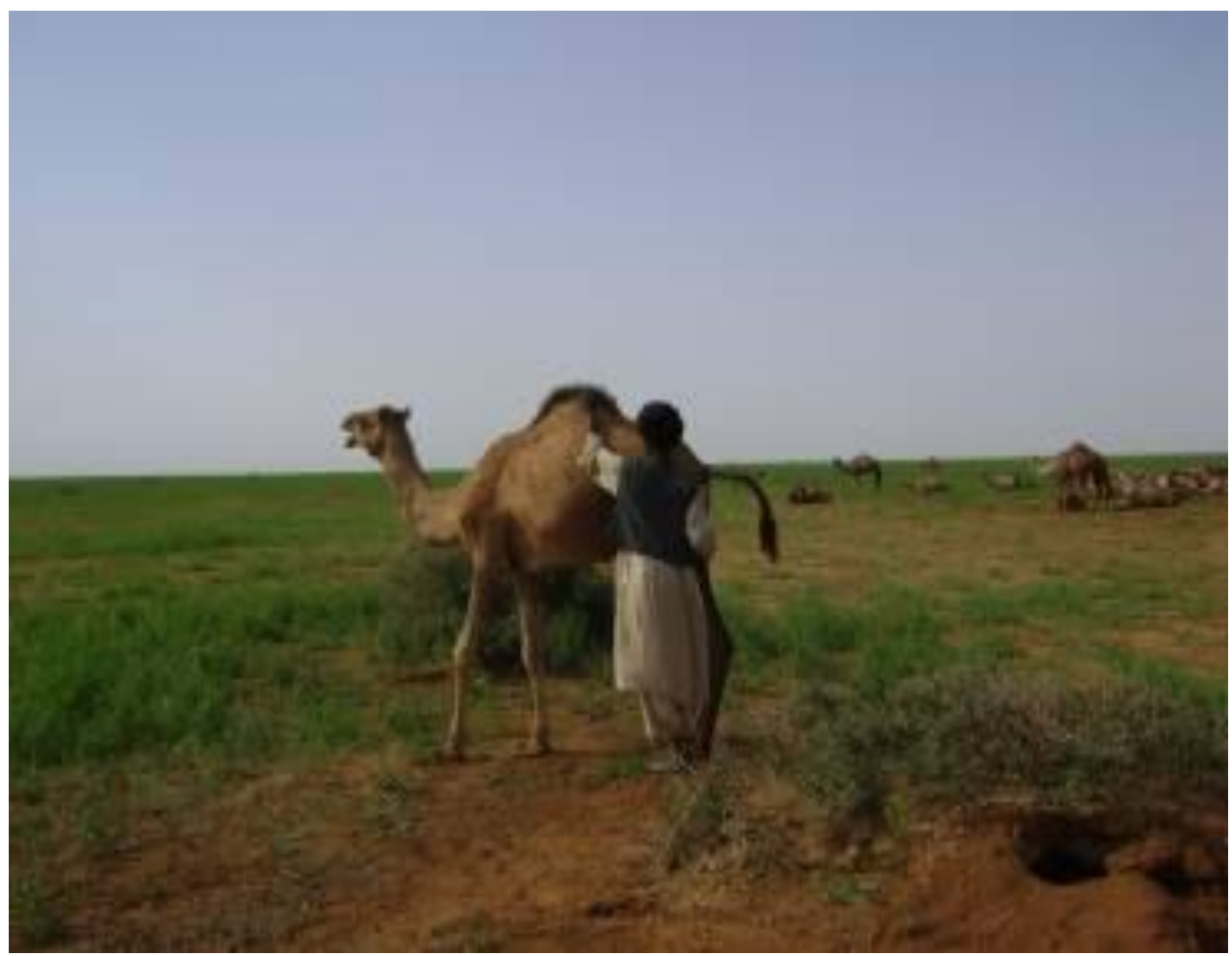


Fig.5 All camel urine samples were identical according to alkaline $\mathrm{pH}$ of the camel urine. Neutralization of camel urine can be done by HCL (10\%) to decrease the PH

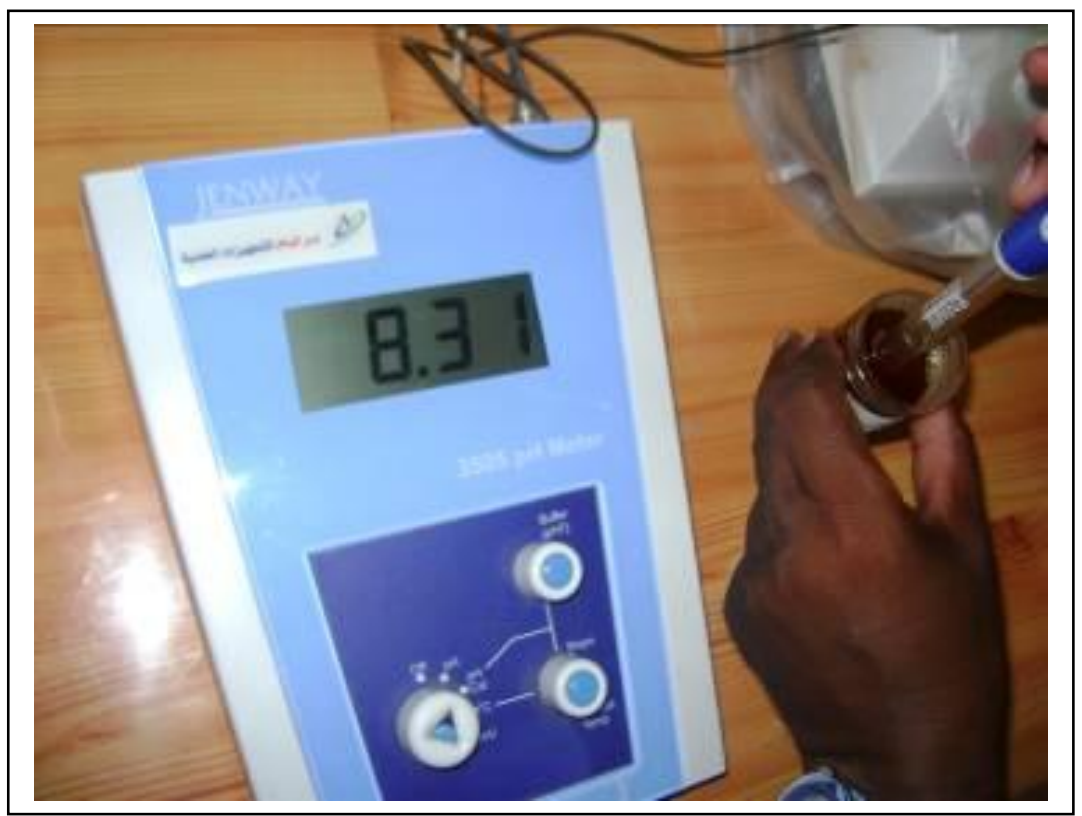

Fig.6 shows $\mathrm{pH}$ of camel urine specimens

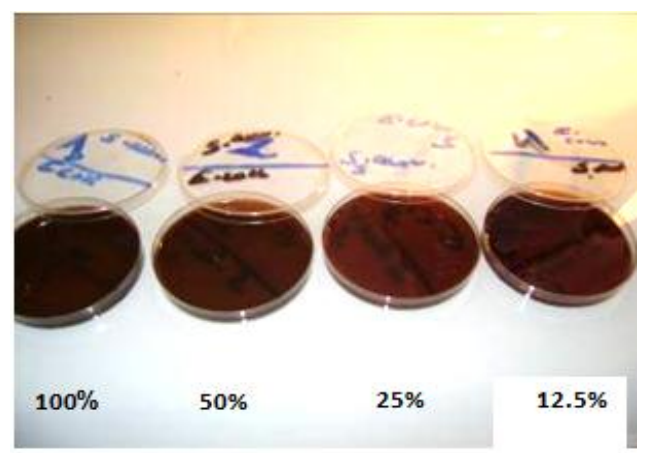

Fig.7 Antimicrobial Susceptibility Test for Camel urine by tube dilution method

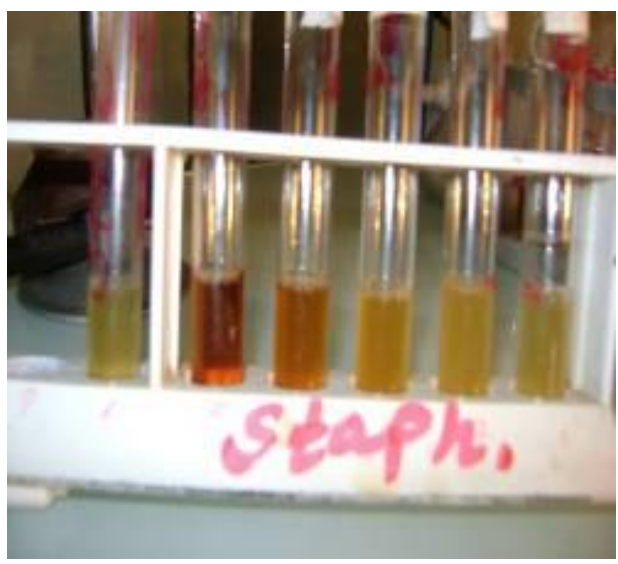


Fig.8 Susceptibility of Camel urine on the isolates

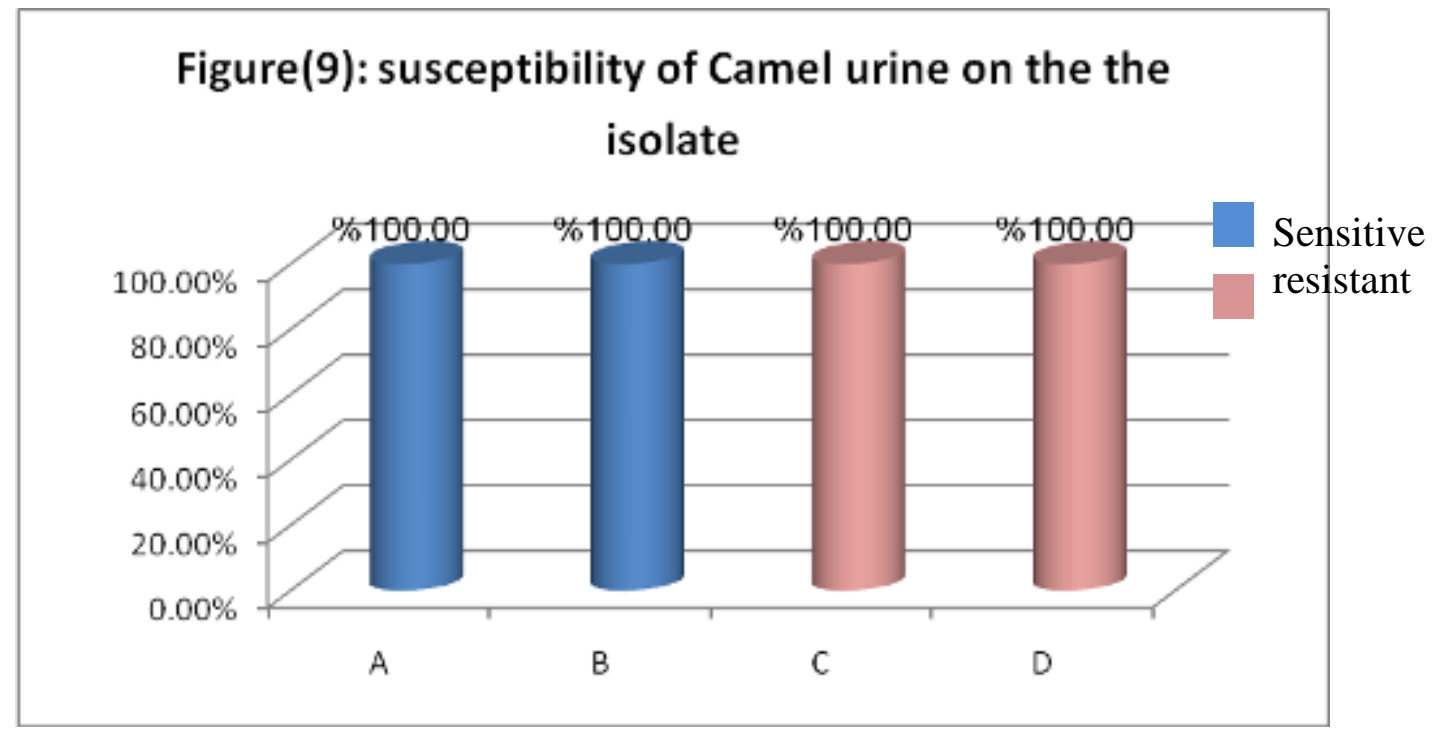

\begin{tabular}{|c|c|}
\hline A & Undiluted camel urine $\mathbf{( 1 0 0 . 0 \% )}$ \\
\hline B & Half diluted camel urine $(50.0 \%)$ \\
\hline C & $25 \%$ Concentrated camel urine \\
\hline D & $12.5 \%$ Concentrated camel urine \\
\hline
\end{tabular}

The results of antimicrobial susceptibility test for camel urine by tube dilution method

The results of antimicrobial susceptibility test for camel urine by tube dilution method in Brain Heart Infusion broth incubated at 37C for 18-24 hours (Figure 7 and 8) Antimicrobial Susceptibility Test for Camel urine by tube dilution method in Brain Heart Infusion broth Inoculated by $0.5 \mathrm{McFarland}$ S. aureus.

The results were:

100\%: No growth (No turbidity)

50\%: No growth (No turbidity)

25\%: Growth (turbidity)

$12.5 \%$ Growth (turbidity)

$6.25 \%$ Growth (turbidity)

Inhibitory concentration $50 \%$
Results of camel urine of different concentration on (Antibiotic resistant) pathogenic bacteria

Camel urine was showed antimicrobial effect either fresh and filtered or stored for six months and filtered on the bacterial growth isolated from wounds infection with their resistance towards antibiotics. Application of the filtered and undiluted female virgin camel (100\%) concentration on the culture media instead of distilled water leads to bactericidal effect for all the isolated of infected wounds,50\% filtered camel urine concentration reported as bacteriostatic and $25 \%$ camel urine concentration was resistant for the isolates.

Inhibitory concentration of camel urine was $50 \%$ and bactericidal concentration was $100 \%$. 
Undiluted and filtered female camel urine of age 5 years $(100 \%)$ and half diluted $(50 \%)$ concentrated were found to be susceptible $100 \%$ for all the isolates of wounds infection.

\section{Recommendation}

We recommend that further studies should be done on the camels' urine for the in vivo using a different animal laboratories and human volunteer for the trail effect of the antimicrobial agent of the camel urine.

\section{References}

Abdalla,. A. (1979): Morphometric observations on the kidney of the camel, Camelus dromedarius. Journal of Anatomy. 129 (1):45-50

Ahmadani (2001): Camel's urine as treatment for dropsy and cirrhosis. Downloaded from www.bab.com.

Al-Ewadi and Haikal (1997): Effect of camel urine on the growth of Aspergillus niger, First Arab conference of applied chemistry, p21-181 Cairo-Egypt.

Al-Ewadi,. and Al-Jedabi, (2000): Antimicrobial agents in camel's urine. The international conference, Mansoura University. J. Union Arab Biol., Cairo 9: 265-281.

http://www.drugresearcher.com

Al-Judaibi, Awatif (1999): studies on the action of antifungal of camel's urine for some pathogenic fungi (M. sc. Thesis). Supervisor: Dr. Ahlam Al-Awadi. (Science College) Jeddah, K.S.A. P.146 $-166$.

Al-Kabarity, A.M.; Al-Mazroee, S. and AlGondi, A. (1987):

\section{How to cite this article:}

Jamal Bayed, S., A. Mohammed issa, Abdul Bagi A. Jubara and Rabie Ali Babiker. 2019. Antimicrobial Effects of Camel's Urine in Bacteria Isolated from Clinical Specimens of Wounds Collected from Patients Admitted in Kassala Teaching Hospital, Sudan. Int.J.Curr.Microbiol.App.Sci. 8(12): 2717-2728. doi: https://doi.org/10.20546/ijcmas.2019.812.318
Ba-hatheq, A. (2006). Antibacterial Effect of Camels Urine on Some Pathogenic Bacteria, Thesis Submitted in partial fulfillment of the requirement for the Master's degree in the Department of Botany \&Microbiology at The College of Science King Saud University.

Camel urine as a possible anticarcinogic agent. Arab Gulf. J. Scient. Res. Agric. Biol. Sci, B6 (1).

Chakraborti, P., First Edition, (1998): Antimicrobial Therapy in A text book of microbiology (, publisher: New central book agency, Calcutta-India, 11:79-82.

EL- Mishad, A. (1987). Antibiotic sensitivity tests, (in text book of medical microbiology), Cairo- Egypt, 9: 38-40.

Jamal, B.S. (2010), In vitro assessment of antimicrobial effects of camels' urine. Master thesis, Department of Microbiology, Collage of Medicine University of Juba, Sudan.

Mokhtar M.O. (2006). Brucellosis in camels in Kassala state, M.sc. thesis, Sudan academy of sciences, 1:6

Muhammad, U.M. (1998), A study on the chemical composition and some medical uses of the Urine of the Arabian camel. Master thesis, Department of applied chemistry, Al-Jazira University, Sudan.

Sahih Bukhari, Ablutions (Wudu'), Volume 1, Book 4, Number 234)" and Muslim (1671).

Shoieb, A. and. Ba-hatheg, A. (December, 2007) Effect of camel urine on pathogenic $P$. aeruginosa and E. coli isolates Towards it's maintains to their antibiotics and the presence of plasmids. 